Article

\title{
Comparative Analysis of Two Assessment Methods for the Geoeducational Values of Geosites: A Case Study from the Volcanic Island of Nisyros, SE Aegean Sea, Greece
}

\author{
George Zafeiropoulos * and Hara Drinia (D) \\ Department of Geology and Geoenvironment, National and Kapodistrian University of Athens, \\ Panepis-timiopolis, Athens 15784, Greece; cntrinia@geol.uoa.gr \\ * Correspondence: georzafeir@geol.uoa.gr
}

check for updates

Citation: Zafeiropoulos, G.; Drinia, H. Comparative Analysis of Two Assessment Methods for the Geoeducational Values of Geosites: A Case Study from the Volcanic Island of Nisyros, SE Aegean Sea, Greece. Geosciences 2022, 12, 82. https:// doi.org/10.3390/geosciences12020082

Academic Editors: Karoly Nemeth and Jesus Martinez-Frias

Received: 17 January 2022 Accepted: 7 February 2022

Published: 10 February 2022

Publisher's Note: MDPI stays neutral with regard to jurisdictional claims in published maps and institutional affiliations.

Copyright: (C) 2022 by the authors. Licensee MDPI, Basel, Switzerland. This article is an open access article distributed under the terms and conditions of the Creative Commons Attribution (CC BY) license (https:// creativecommons.org/licenses/by/ $4.0 /)$.

\begin{abstract}
In this study, the geoeducational value of five geosites, located in the aspiring geopark of the volcanic island of Nisyros, SE Aegean Sea, was assessed by means of two methods: the G-P method of Brilha (2016) and the M-GAM method. The first method takes into account 12 criteria belonging to the educational potential. The M-GAM method, on the other hand, takes into account the opinions of visitors who, as non-experts, express a different point of view that is rarely calculated or evaluated in different geosite assessment methods. For the better and more objective comparison of the two methods of evaluation of the educational potential of the study areas, the results were converted to a percentage scale (\%). The first G-P method clearly highlights the high geological value of the studied geosites, which have a relatively high score and can be used for geotourism and geoeducation. The second method, on the other hand, yields a moderate score in areas with objectively high geological value. This is clearly evident, as this method considers the opinions of visitors who lack the necessary cognitive geological background, thereby underestimating the significance and potential of certain geological features due to lack of formal training.
\end{abstract}

Keywords: geoeducation; geoheritage; geosite quantitative assessment; Nisyros Island

\section{Introduction}

In recent years, an effort has been made by the geoscientific community to record, evaluate, and highlight sites of high geological interest. A key role in this initiative was played by the Convention on the Protection of the World Cultural and Natural Heritage that took place in Paris (France, 1972) and, some years later, by the International Declaration on the Rights of the Memory of the Earth, held in Digne (France, 1991) [1]. These two events were the precursors to the creation of a European initiative for the protection of geoheritage and geodiversity. Indeed, the European Geoparks Network (EGN) was established in 2000 with its goal being the systematic dissemination of procedures that would ensure the protection and conservation of geodiversity [2]. A few years later, in 2004, the Global Geoparks Network was established to enhance the value of geological heritage to both geoscientists and the public [3], as well as to promote sustainable development in areas hosting such geoparks. The above initiatives have led to the emergence and documentation of the new geoscientific concepts of geodiversity and geoconservation. According to Zwolinski, [4] geodiversity is defined as the variety in the earth's materials and the forms and the processes that compose and shape the Earth. Sharples [5] states that geoheritage incorporates the protection of dynamic geological processes and geodiversity. Thus, a new need arises for the protection and conservation of areas of high geological value. This need has led to the concept of geoconservation, which denotes all actions taken to preserve and enhance geological and geomorphological features, processes, sites, and specimens [6,7].

In addition, a set of innovative activities is beginning to develop, closely linked to geoeducation and geotourism, based on the principles of sustainability and rational 
environmental management [8,9] and the conservation of the geoenvironment, geoheritage, and geodiversity of a geologically important area. Geotourism is gaining popularity as an alternative form of tourism that focuses on criteria of social, cultural, environmental, and economic sustainability, in order to achieve benefits not only for society and its citizens, but also for the environment itself.

Quantitative assessment of geoheritage is now considered essential for the development of geotourism and geoeducational activities. In this respect, a number of inventory and assessment methodologies have been developed to protect and promote geoheritage and to document its geoeducational and geotouristic value (e.g., [10-21]). These assessment methods were developed to evaluate the scientific, educational, touristic, and other values of geosites to determine which types of geosites are the most valuable and can be used as tourist attractions or for geoeducational activities. These methods differ from each other, mainly in the criteria they adopt, which in most cases are dependent on the perspective of each researcher. This results in the quantification of the criteria not being carried out in a purely objective way, as subjectivity enters, causing distortions in the final results [13,22-33]. For this reason, there is a risk of misinterpretation and misjudgment when the evaluation is not carried out based on well-documented and objective criteria $[34,35]$. On the other hand, there are assessment methods that employ mathematical approaches and models to provide a more quantitative and multidisciplinary perspective of areas of high geoscientific interest. In fact, some models consider not only the scientific value that may arise but also the geoeducational perspective on and potential of these areas [13,22,34-40].

The main purpose of this article is to assess geosites using two quantitative assessment methodologies that approach the geoeducational value of a geosite in different ways. The first method, used by Brilha [17], is considered a general-purpose method (G-P method) designed to assess any type of geosite, considering a wide spectrum of criteria. This method emphasizes four parameters: the scientific value (SV) determined by the study area, the potential educational use (PEU) offered by the potential geosite, the potential tourist use (PTU), and the risk of degradation (DR) of the area. It is one of the most popular and applied inventory methods.

The M-GAM (Modified Geosite Assessment Model) developed by Tomić and Božić [36] is a combination of the GAM model created by Vujičić et al. [41] and the importance factor (Im) first introduced by Tomić [42] in his research. In this research project, the viewpoints of visitors were considered during the evaluation process. A survey was used to gather information. Along with the assessment criteria from Vujičić et al. [41], a new element called the importance factor ( Im) was added to the evaluation process. This factor enabled visitors and tourists to express their thoughts on the significance of each subindicator in the assessment model. The advantage of this evaluation model is that it incorporates the perspectives of both experts and visitors [36,37]. This is the first time that this method has been applied for the evaluation of geosites in Greece.

The ultimate goal is to compare the results of the two methodologies and to decide which method is most appropriate for determining the educational value of a geosite. The island of Nisyros was selected as a case study.

The volcanic island of Nisyros is an aspiring geopark, located in the SE Aegean Sea, in the Dodecanese island complex. It is distinguished from the neighboring islands by significant geodiversity related to its long and complicated geological history. Particularly interesting is that in this small region, there are volcanic rocks representing five episodes of volcanism. Therefore, Nisyros is widely recognized as a geological museum, attracting many geologists as well as alternative tourists who are awestruck by its wild natural beauty. Its rich volcanic history, steaming hydrothermal craters, intense smell of sulfur and fumarolic gases, and hot springs, together with the island's rich human history, astound visitors [43]. 


\section{Materials and Methods}

\subsection{The Study Area}

Nisyros Island is the youngest volcano of the South Aegean Active Volcanic Arc, which resulted from the subduction of the Eastern Mediterranean lithosphere beneath the active Hellenic margin of the European plate. It is part of the Kos-Yali-Nisyros Volcanic Field, which is located on the easternmost edge of the South Aegean volcanic island arc. (Figures 1 and 2) [43].

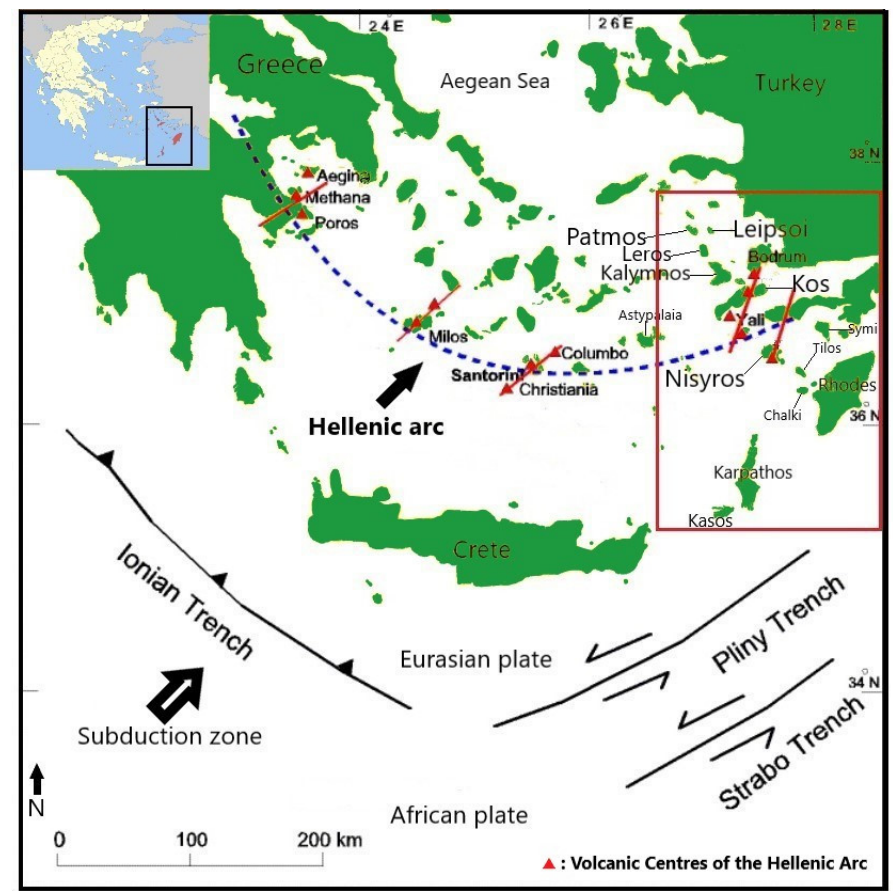

Figure 1. Location of the Dodecanese complex in the southeastern branch of the South Aegean Active Volcanic Arc, at the convergence limits of the two lithospheric plates, the Eurasian and the African.

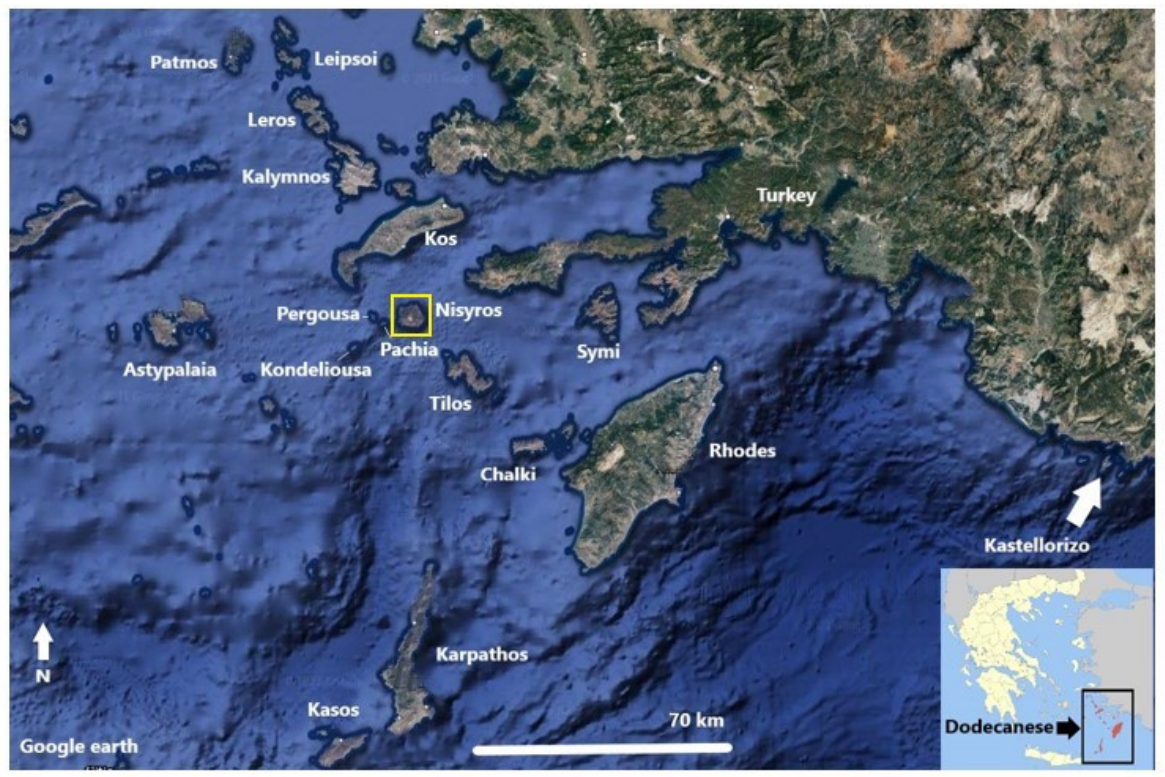

Figure 2. Satellite photo of the Dodecanese island complex, SE Greece, indicating the location of Nisyros Island; Inlet: Sketch map of Greece indicating the location of Dodecanese island complex. 
Nisyros has a stratovolcano-like structure formed during the Late Pleistocene-Holocene period within an ENE-WSW-trending neotectonic graben $[44,45]$. Its stratigraphy is characterized by intercalations of andesitic lavas with andesitic pyroclastic deposits bound by feeder systems of sills and dykes of similar composition that can be seen in the cores of geothermal energy test drillholes (Figure 3). The exposed stratigraphy begins with pillowed basaltic andesite and pillow breccia and progresses to more felsic volcanism, culminating in rhyodacitic post-caldera domes $[44,46]$.
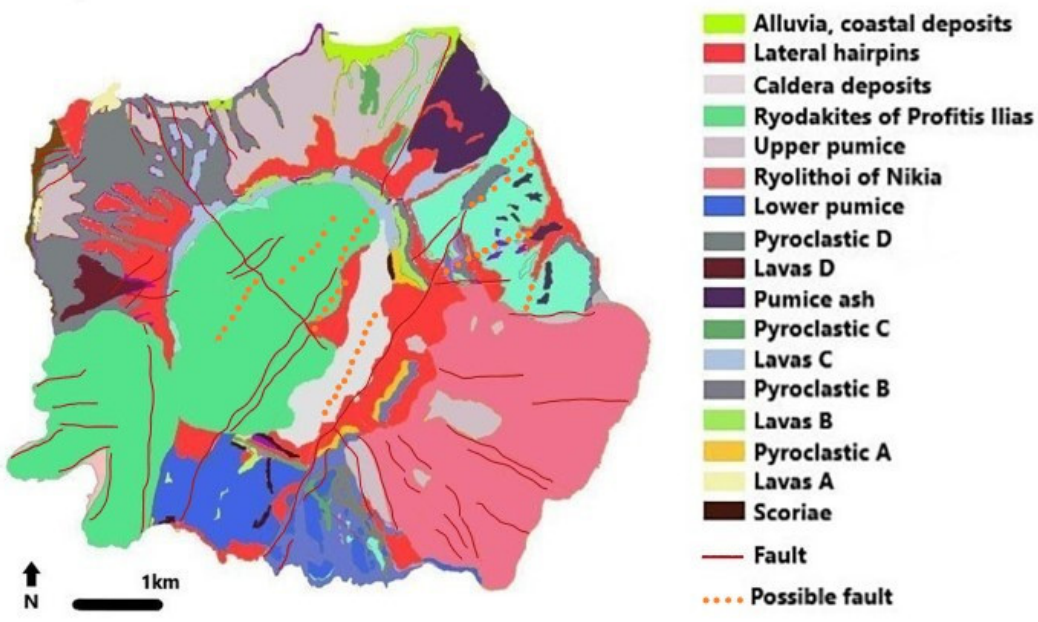

Figure 3. Geological map of Nisyros [44], modified.

The recent form of the caldera is a well-defined circular topographic feature with a diameter of $4 \mathrm{~km}$, with a presently flat caldera floor intercepted by phreatic craters with cliffs of up to $300 \mathrm{~m}$ [43]. The top of the Profitis Ilias (Figure 4) post-caldera dome is the highest point $(698 \mathrm{~m})$ [44,47-50]. The exposed stratigraphy has an age of $-160,000$ years [49], and the most recent phreatic eruption occurred in 1867 A.D. [51].

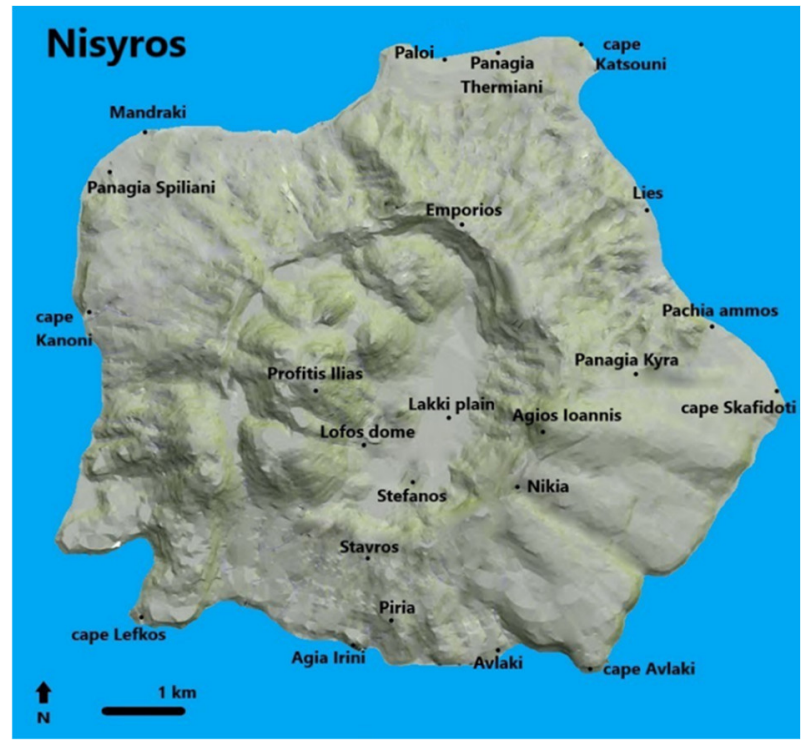

Figure 4. 3D representation of the surface of Nisyros Island, indicating the location of places referred in the text [52], modified. 
The caldera hosts a well-known hydrothermal-fumarolic field, whose hydrothermal activity is expressed on the surface by a network of intersecting hydrothermal craters, located in the southern part of the Lakki plain (Figure 4). These craters are governed by diffuse degassing structures. [44,53-57]. The most well-known hydrothermal craters are: Stefanos, Phlegethon, Megalos Polyvotis, and Mikros Polyvotis (Figure 5). [44,53]. The volcano's last crater, "Mikros Polyvotis", was formed in 1887, following the volcano's last—so far-hydrothermal explosion.

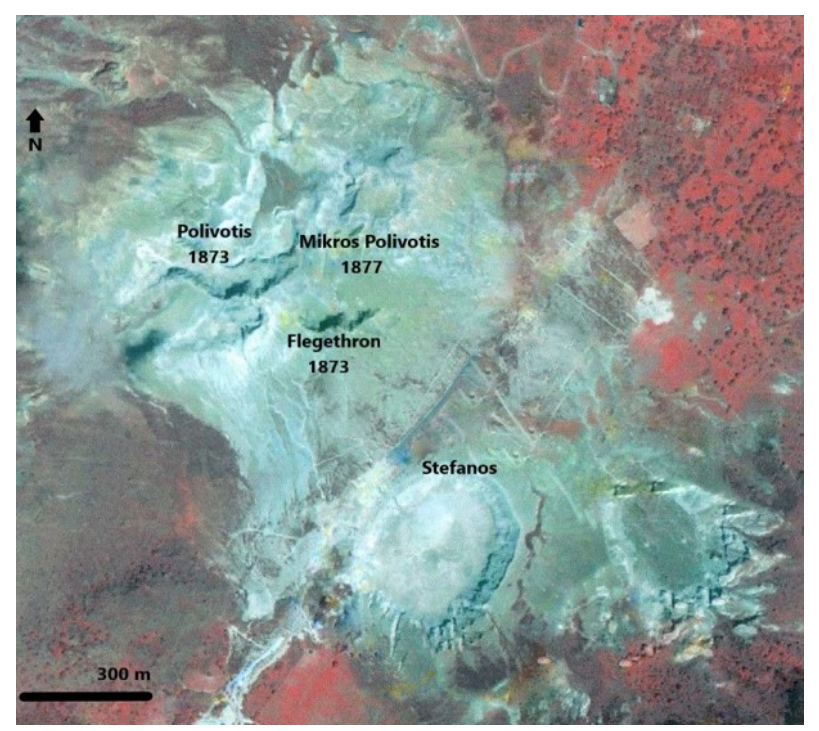

Figure 5. Satellite photo of the craters [58], modified.

The Nisyros caldera is also particularly noteworthy for the presence of epithermal gold in the Lofos dome area (82 ppb) and the adjacent Profitis Ilias area (2500 ppb), indicating the presence of significant hydrothermal circulation phenomena [57].

Various authors have studied the evolution of Nisyros Volcano over the last 160,000 years, as well as the succession of calc-alkaline lavas and pyroclastic rocks. The first geographic and geological studies on Nisyros Island were conducted by the Italian geologists Martelli [51] and Desio [59]. Detailed geological studies began in the late 1960s [60] and were carried on by Di Paola [49] and Papanikolaou et al. [44]. According to them, the island's volcanic history is divided into five stages:

(1) The lower volcanic rocks visible on the northern coast near Mandraki were built up by an underwater volcano with erupting basaltic and andesitic pillow-lavas;

(2) For more than $100 \mathrm{ka}$, a 500-700 m high stratovolcano grew on top of these partly submarine lavas;

(3) Two major rhyodacitic plinian eruptions covered the entire island with pyroclastic flows and pumice falls after several eruptive phases of gas and steam explosions;

(4) At $20 \mathrm{ka} \mathrm{BP}$, a major central, vertical collapse of the volcano left a large caldera; and

(5) The western part of the caldera depression was filled with a series of rhyodacitic domes during prehistoric times, the highest of which, Profitis Ilias, rises $698 \mathrm{~m}$ a.s.l.

For at least $25 \mathrm{ka}$, no volcanic activity is known to have occurred on the island following the formation of the domes; the only reported historical explosions are associated with the formation of several phreatic craters inside the caldera, such as Alexandros, Polyvotis, Stephanos, Phlegethon, and Achelous, which are still emitting fumaroles. The most recent hydrothermal eruptions in 1871-1873 and 1887 AD were accompanied by violent earthquakes, gas detonations, steam blasts, and mudflows [57].

The major distinction in Nisyros' volcanic history is the first period of stratovolcano formation, which ended with a major eruption (Nikia rhyolites) and caldera formation, followed by the second period of volcanic dome formation, which disrupted the former 
caldera rim (now observed at about $300 \mathrm{~m}$ of elevation) and formed the highest actual mountain of Prophitis Ilias (698 m). Recent volcanic formations in the submarine area around Nisyros have created the volcanic centers of Pergousa, Yali, Strongyli, Pachia, and Kondeliousa (Figure 6) [61,62].

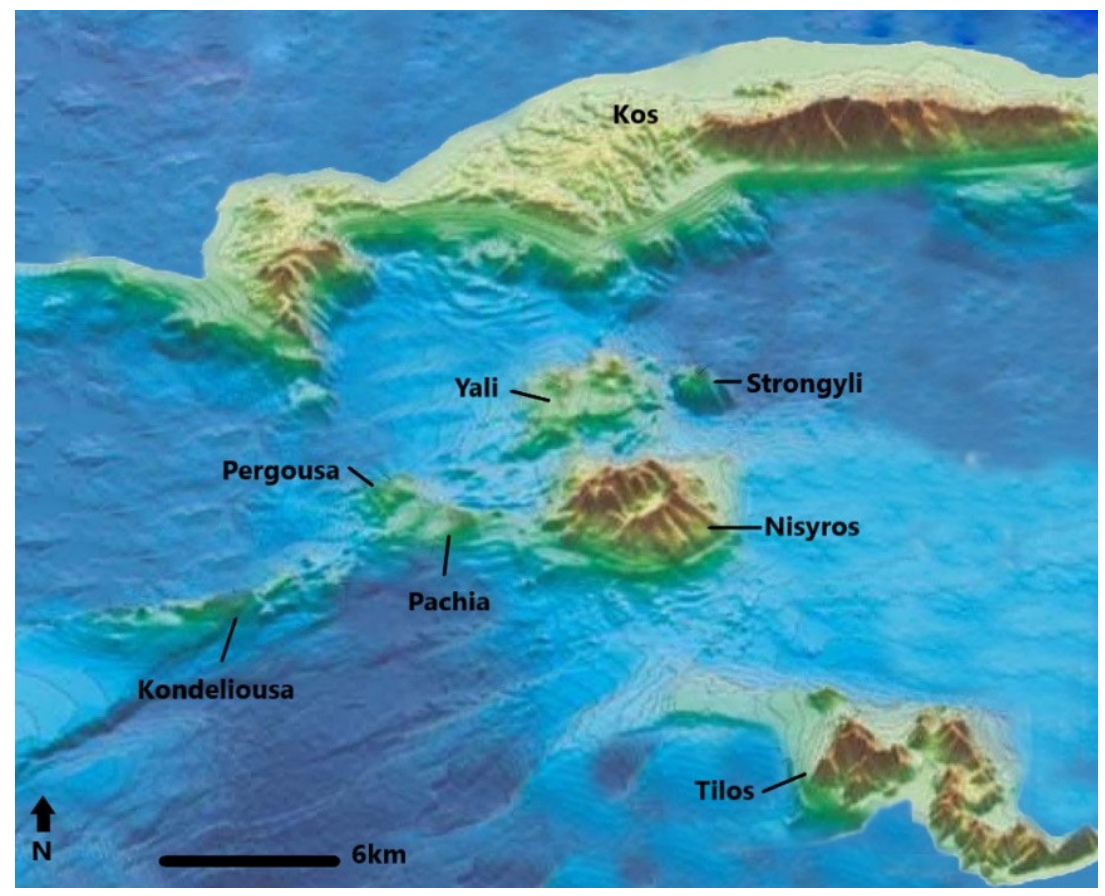

Figure 6. Nisyros and the other smaller island around [63], modified.

After several years of inactivity, an intense seismic activity began at the end of 1995 and lasted until 1998, with the largest event recorded on 27 August 1997, with a Ms of 5.3. [64]. This activity resulted in significant variations in fumarole geochemical parameters and progressive uplift and E-W extension of the island's central parts, as well as a possible magma input at greater crustal depth. [63-65]. This gradual uplift resulted in a large $\mathrm{N}-\mathrm{S}$ trending fracture known as the "Lakki rupture" in the caldera's Lakki plain in early December 2001 [65].

Due to the volcanic activity, there is a significant risk in the wider area for both residents and visitors. As a result, the Volcanological Observatory of Nisyros was established with a suitable and equipped network for monitoring the volcano's physicochemical parameters. In this manner, a valid prediction of the volcano's reactivation can be made in order to take immediate protective measures.

\subsection{Geosites}

Nisyros Island hosts numerous interesting geosites, ranging from the enormous volcanic craters of the caldera and the thermal springs to the volcanic islets that surround it. The island's landscape is home to a diverse range of magnificent volcanic landforms shaped by natural processes, where visitors can experience the immense power of volcanoes. All the geosites provide accessibility to enjoyable recreation activities. In addition to the fumarolic activity found in the well craters, gas escape is also observed along the active tectonic zones that intersect the island. Thermal springs with temperatures ranging from $27^{\circ}$ to $43^{\circ} \mathrm{C}$ are situated near the coast. Isotopic analysis of Nisyros thermal water samples revealed a mixture of seawater, magmatic water, and geothermal steam, as well as the possibility of groundwater and/or meteoric water involvement.

In this study, five geosites were selected (Figure 7). Each geosite has been labeled with an ordinal number and the letters "GS". 


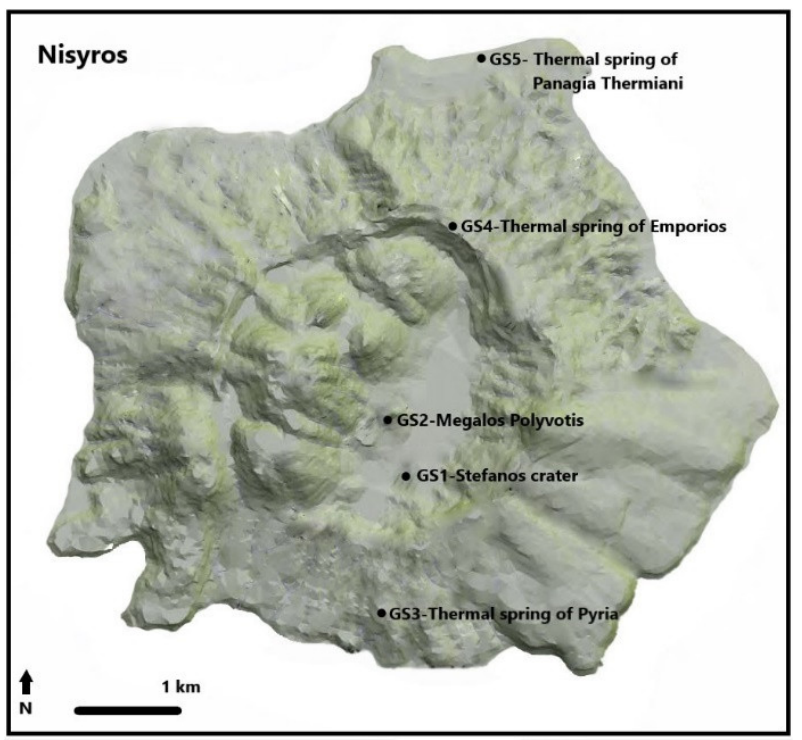

Figure 7. 3D representation of Nisyros Island, indicating the location of the studied geosites [57], modified.

GS1-Stefanos Crater (Figure 8a,b): With dimensions of $260 \times 350 \mathrm{~m}$, the elliptical Stefanos Crater is one of the world's largest phreatic craters. Its shape appears to be the result of two main NE-trending active faults characterized by an alignment of fumarolic vents. The crater has a maximum depth of $27 \mathrm{~m}$. The age of the crater's formation is unclear. On the eastern walls of Stefanos, seven stratigraphic layers have been recognized: talus of magmatic lithics, epiclastics and fine argillitic layers, fine-grained lacustrine deposits, solid deposits of explosive compounds generated by the Kaminakia craters, deposits from Stefanos' explosion, and a thin coating of explosive products from Polyvotis are among them. The surrounding area of the crater of Stefanos is characterized by intense and spectacular activity, which is due to the release of gases with a temperature of $100{ }^{\circ} \mathrm{C}$. The gases consist of water vapor and carbon dioxide. Hydrogen sulfide, nitrogen, and methane are released at a smaller rate of about $0.5 \%$ [57,66-68]. It is worth noting that amorphous sulfur crystals are deposited at the mouths of the holes from the gas outlet, while the liquefied water vapor irrigates the surrounding soil with dilute sulfuric acid, due to the dissolution of hydrogen sulfide in the steam. Stefanos crater favors the concentration of gases due to its elliptical shape $(260 \times 190 \mathrm{~m})$. Therefore, it has been observed that in periods of volcanic activity and intense hydrothermal vents, large amounts of gases are released and seismic events occur, which in turn cause landslides.

The characteristic strong and not-so-pleasant smell that exists in the surrounding area is due to the existence of hydrogen sulfide, which even in infinitesimal concentrations is felt by every visitor.

GS2-Megalos Polyvotis (Figure 8a): Megalos Polyvotis was formed because of the Lofos area's first and most powerful hydrothermal explosive cycle. It is an elliptical (180 $\times$ $350 \mathrm{~m}$ ) crater with 3-5 m thick ejecta that is partly covered by products originating from Flegethron or Alexandros crater (Figure 8c), which is a large elliptical-shaped crater that occupies the southeastern part of the area, intersecting with Megalos Polyvotis, from a later event. The crater's material is made up of altered lava fragments and rhyodacitic blocks in a clayey-to-sandy matrix. The lava blocks are surrounded by brown-reddish oxide coatings and cut by anhydrite veins. Its stratigraphy is like that of Stefanos, with lacustrine sediments and unconsolidated clay material at the bottom and chaotic ejecta of earlier magmatic products at the top. After heavy rainstorms, the western sector of the crater floor usually turns into a lake, and it is composed of $1.5 \mathrm{~m}$-thick yellow- and purple-colored varved clayey layers, indicating the past presence of a lake.

GS 1 and GS 2 strongly differ in their morphological characteristics. The crater of Stefanos (GS1) creates a negative relief, whereas the crater of Polyvotis (GS2) creates a 
positive one. The positive relief of Polyvotis is probably due to the existence of ridges from the adjacent post-caldera structures, which are located around the perimeter of this crater along with the materials from the well explosions. The deposits of Stefanos and Polyvotis craters consist mainly of clay materials that inhibit the deeper penetration of water, resulting in the retention of rainwater, leading to an increase in soil moisture. The simultaneous vapor activity results in the formation of small craters of hot mud.


Figure 8. Geosites of Nisyros Island: (a) the Stefanos and Polyvotis craters, (b) the Stefanos crater, (c) the Alexandros crater, (d) the Piria hot spring, (e) natural hot spring of Emporios, and (f) Panagia Thermiani thermal spring. 
GS 3-thermal spring of Pyria (southern part of the island, Figure 8d): In 1841, during a visit to the island by the German archaeologist Ludwig Ross from 9-11 August, he described and depicted several areas with hydrothermal activity. In particular, he states that in Pyria (Arodafnes area), a great heat is exuded, probably due to the strongly cracked southern slopes of the caldera of the island. In fact, these cracked areas appear along the rupture zone that runs in a SW-NE direction $[43,44]$. In its original form, the thermal spring included a stone building complex with 5-6 chambers. Today, only the chamber where natural steam at a temperature of $40-45^{\circ} \mathrm{C}$ is released is intact and in good condition. The source is still used by locals and visitors for the same purpose.

GS4-thermal spring of Emporios (Figure 8e): This is located at the entrance of the settlement of Emporios (northeast of the island) and exhibits temperatures between 36 and $40{ }^{\circ} \mathrm{C}$. This phenomenon is due to the cracked zone (NE) that exists in contrast to other systems [44]. In addition, it shows a divergent direction compared to the other fault systems (south, west, and east sides of the island), resulting in the transport and circulation of hydrothermal fluids in several cases [43]. In fact, the length of the fault throw created by the faults in these areas in places reaches up to $100 \mathrm{~m}$; therefore, it is perceived that this location is inextricably linked to geothermal interest [44]. As a result, in this small chamber, the diffusion of heat is perceived as well as the sulfur that is perceived (yellowish appearance on the surface of the rocks) on the inner surface of the space.

GS5-thermal spring of Panagia Thermiani: This water spring is located in the northern part of the island (near the settlement of Paloi), next to the small church of Panagia Thermiani (Figure 8f). Thermiani is one of the Nisyros thermal springs that have been evidenced since antiquity. Roman baths have been found there, at least ruins and inscriptions proving their past glory. In 1889, a doctor named Pantelis Pantelidis operated a medical unit in which he exploited the water that gushed from this source. The high salinity of this spring may be due to the underground circulation of water in pyroclastic formations, as well as to geological structures that reveal fault zones. The spring is affected by the infiltration of seawater; therefore, there is an admixture of several minerals and various meteoric components, since a perpetual interaction is observed between the sources and the specific geological formations. The source is rich in $\mathrm{SO}_{4}^{2-}, \mathrm{Mg}^{2+}, \mathrm{Cl}^{-}$, and $\mathrm{HCO}^{3}$. Water here is a mere 33 degrees, but it is equally refreshing and healing.

This spring is due to the geothermal activity of the island as well as to the northern ruptured zone that exists [68-72].

\subsection{Methodology}

In this study, two methods of geosite assessment were applied. The first method is the general-purpose method of Brilha [17] (G-P method). This method was chosen due the broad criteria that allow the evaluation of any type of geosite and have been applied in several studies. It provides a quantification proposal consisting of four factors: scientific value (SV), potential educational use (PEU), potential touristic use (PTU), and degradation risk (DR). The quantitative evaluation of the scientific value (SV) of a geosite includes the following seven criteria: representativeness, key locality, scientific knowledge, integrity, geological diversity, rarity, and use limitations. The first term refers to a geosite's potential to highlight a geological process or a variety of features. The term "key locality" corresponds to the geosite's significance as a reference point for various geological features. If there are national or international publications, "scientific knowledge" plays an important role. "Integrity" denotes the geosite's conservation status. The term "geological diversity" corresponds to the quantity of different geological elements found in each geosite. The term "rarity" is used to explore whether there are geosites with similar characteristics in the same area. Finally, the term "use limitations" refers to the obstacles and limitations that may make research and study of the geosite difficult.

Regarding the quantitative assessment of the educational potential use (PEU), twelve criteria are estimated: vulnerability of a geosite, its accessibility, use limitations, safety, logistics, density of population, association with other values, scenery, uniqueness, obser- 
vation conditions, and didactic potential. The vulnerability is centered on the presence of geological elements that can be affected by visitors. Beyond that, this method investigates the accessibility of the geosite, including the use limitations if there are any. Furthermore, the status of safety and the potential facilities that could be provided are investigated. In addition, the population density and the association of the geosite with other values such as cultural, aesthetic, and so on are determined. The method is then based on the scenery of the area and its uniqueness. Furthermore, the observation conditions and didactic potential are investigated.

For the quantitative assessment of the geotouristic potential (PTU), 13 criteria are used, the first ten of which are similar to those used for educational purposes, and the remaining three of which take into account the interpretative potential, the economic level of the people who live in the area, and the proximity of recreational areas.

Each of the criteria was assigned a score from 1 to 4 , with 1 indicating a low possibility of use and 4 indicating a high possibility of use for SV, PEU, and PTU.

The degradation risk (DR) refers to the possibility of a geosite being damaged or destroyed, i.e., losing any of the characteristics that make it valuable as a geosite $[29,30,73,74]$. Finally, five criteria for evaluating and quantifying degradation risk (DR) are considered: deterioration of geological elements, proximity to areas/activities with potential to cause degradation, legal protection, accessibility, and population density.

Weighing criteria are used to complete the geosite quantification process. Weights were applied to each of the quantification criteria based on their importance in order to examine the potential for scientific, educational, and tourist use. Weights are also assigned to each of the criteria based on their importance in assessing the degradation risk of geosites. The weights used in this study are according to Brilha [17] and are shown in Table 1.

According to G-P method categorization, the geosites can be classified as having a low, medium, or high degradation risk based on the criteria.

Regarding the second method, M-GAM (Modified Geosite Assessment Model), this originated from the differentiation of the GAM method introduced by Vujičić et al. [41]. The method is based on previous geosite assessment methods modified by Tomić and Božić [36] and applied by several scientists [75-85]. The innovation of this method is that it considers the opinion not only of experts but also of visitors to a specific geological area. As a result, M-GAM is used to assess the scientific, educational, and tourist value of a geosite while also assessing the visitors' point of view, regardless of their geological knowledge background. However, it should be mentioned that in the present method, the evaluation is done with a mathematical model, so that there is an equal estimation of both methods, without affecting each other.

In this method, two main components are considered, the main values (MV) and the additional values (AV). The main values are divided into 12 criteria and the additional values into 15. The main values consider the abiotic characteristics of a geosite, while the additional values mostly concern the human activities carried out in relation to each geosite.

The following three aspects are included in the main values: scientific/educational value (VSE), scenic/aesthetic value (VSA), and protection (VPr). The following characteristics are included in the VSE field: rarity, representativeness, scientific issue knowledge, and interpretation level. The following aspects are included in the VSA field: viewpoints, surface, surrounding landscape and nature, and environmental fit, meaning contrast to the nature, contrast of colors, appearance of shapes, etc., of site. Finally, the following factors are involved in the VPr field: current condition, protection level, vulnerability, and appropriate number of visitors. The main values are estimated using the following equation: $\mathrm{MV}=\mathrm{VSE}+\mathrm{VSA}+\mathrm{VPr}$.

The additional values comprise two parameters: functional values (VFn) and touristic values (VTr). The estimation of the additional values is computed from the equation $\mathrm{AV}=\mathrm{VFn}+\mathrm{VTr}$. 
Table 1. Calculation of the final scores in the G-P method.

\begin{tabular}{|c|c|c|}
\hline Factors & \multicolumn{2}{|l|}{ Criteria } \\
\hline \multirow{7}{*}{ Scientific Value $(S V)=$ SUM of the criteria } & Representativeness & $30 \times$ score \\
\hline & Key locality & $20 \times$ score \\
\hline & Scientific knowledge & $5 \times$ score \\
\hline & Integrity & $15 \times$ score \\
\hline & Geological diversity & $5 \times$ score \\
\hline & Rarity & $15 \times$ score \\
\hline & Use limitations & $10 \times$ score \\
\hline \multirow{12}{*}{ Educational Potential Use $(P E U)=$ SUM of the criteria } & Vulnerability & $10 \times$ score \\
\hline & Accessibility & $10 \times$ score \\
\hline & Use limitations & $5 \times$ score \\
\hline & Safety & $10 \times$ score \\
\hline & Logistics & $5 \times$ score \\
\hline & Density of population & $5 \times$ score \\
\hline & Association with other values & $5 \times$ score \\
\hline & Scenery & $5 \times$ score \\
\hline & Uniqueness & $5 \times$ score \\
\hline & Observation conditions & $10 \times$ score \\
\hline & Didactic potential & $20 \times$ score \\
\hline & Geological diversity & $10 \times$ score \\
\hline \multirow{13}{*}{ Tourism Potential Use $(\mathrm{PTU})=$ SUM of the criteria } & >Vulnerability & $10 \times$ score \\
\hline & Accessibility & $10 \times$ score \\
\hline & Use limitations & $5 \times$ score \\
\hline & Safety & $10 \times$ score \\
\hline & Logistics & $5 \times$ score \\
\hline & Density of population & $5 \times$ score \\
\hline & Association with other values & $5 \times$ score \\
\hline & Scenery & $15 \times$ score \\
\hline & Uniqueness & $10 \times$ score \\
\hline & Observation conditions & $5 \times$ score \\
\hline & Interpretative potential & $10 \times$ score \\
\hline & Economic level & $5 \times$ score \\
\hline & Proximity of recreational areas & $5 \times$ score \\
\hline \multirow{5}{*}{ Degradation Risk $(\mathrm{DR})=$ SUM of the criteria } & Deterioration of geological features & $35 \times$ score \\
\hline & $\begin{array}{c}\text { Proximity to areas/activities with potential to } \\
\text { cause degradation }\end{array}$ & $20 \times$ score \\
\hline & Legal protection & $20 \times$ score \\
\hline & Accessibility & $15 \times$ score \\
\hline & Density of population & $10 \times$ score \\
\hline
\end{tabular}

As previously stated, this method takes into account the visitors' viewpoint. This is incorporated in the importance factor ( $\operatorname{Im})$, which is independently assessed by the visitor for each field (rarity, representativeness, etc.) and multiplied by each corresponding subindicator (which is given by experts). In our study, we relied on Tomić and Božić's [36] research for the importance factor, which has values including 0.00 (not at all important), 0.25 (not quite important), 0.50 (neither insignificant nor important), 0.75 (a little important), and 1.00 (quite great importance). The importance factor is defined by the following formula:

$$
I m=\frac{\sum_{k=1}^{K} I v k}{K}
$$

where Iv $k$ is the evaluation/score of each visitor for each field (field-subindicator), and $K$ is the final number of visitors.

Following in the footsteps of Antić, Tomić, and Marković [37], who used the data and results of Božić and Tomić [86] in a geosite assessment survey, we used the importance factor values from the same publication of Božić and Tomić [86]. 
The final results coming out from this method are depicted in a diagram, where the 12 categories studied in the main values are placed on the vertical axis, while the 15 categories of additional values are placed on the horizontal axis. Furthermore, this diagram is divided into 9 fields, which are as follows: starting from the beginning of the axes and referring to the $x$-axis in the fields Z11, Z21, and Z31; moving up to the $y$-axis in the fields Z12, Z22, Z23; and finally, the fields Z13, Z23, and Z33. Each study area's final score is represented by the diagram.

For the better and more objective comparison of the two methods of evaluation of the educational potential of the study areas, the results were reduced to a percentage scale (\%). This process resulted in a disparity between the results of the two evaluation methods. In the context of our research, this reduction was made only for the educational value, since the objective of our study is the evaluation of the geoeducational potential of the geological heritage. More specifically, the maximum possible value by which a study area can be evaluated in the G-P method is 400. As a result, all scores are reduced to a scale with a maximum value of 100. Similarly, the M-GAM method, which can have a maximum effect value in the $\mathrm{Z} 33$ region, follows the same approach. When the horizontal axis (Main Values) is marked with the value 12 and the vertical axis (Additional Values) is marked with the value 15, the maximum possible distance from the beginning of the axes is achieved. The following formula is used to calculate the distance of a point from the beginning of the axes to the plane: $d=\sqrt{M V^{2}+A V^{2}}$ (Figure 9).

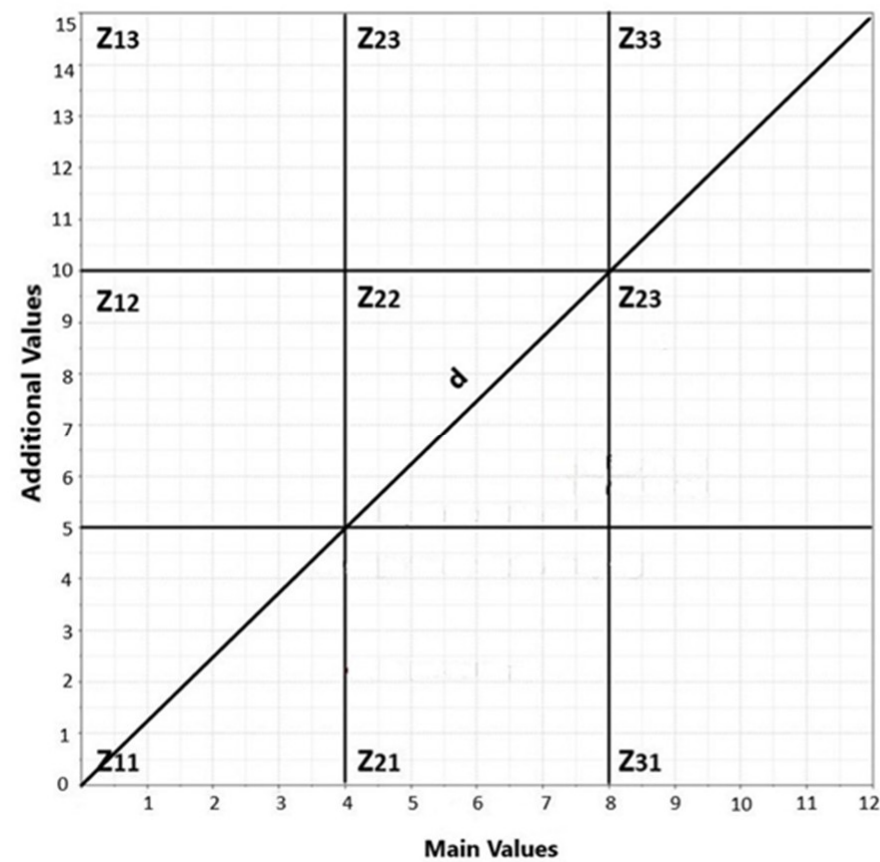

$d=\sqrt{M V^{2}+A V^{2}}$

Figure 9. Maximum potential distance from the origin $0(0,0)$.

In our study, there is a maximum possible value for $\mathrm{MV}=12$ and $\mathrm{AV}=15$ :

$$
d_{\max }=\sqrt{12^{2}+15^{2}} \cong 19.2
$$

Finally, the results are converted to a percentage. As a result, size comparisons on a single scale are possible.

The two aforementioned methods were chosen for two primary reasons. The G$\mathrm{P}$ method is a quantitative evaluation purely for educational purposes, with a set of 12 criteria, each with its own corresponding weight in the final evaluation. As a result, this method approaches a mathematical result with greater objectivity in order to ultimately determine whether the geosite is of educational interest. Second, the M-GAM method 
is groundbreaking in that it incorporates public opinion into mathematical calculations, allowing the scientific community to discern citizens' perspectives as well as perspectives that may not have been considered previously.

\section{Results}

The results of the quantitative assessment of educational use value are described below.

\subsection{The General-Purpose Model—G-P Method}

The results of this method are shown in Tables 2-6.

Table 2. Quantitative evaluation of geosites for scientific value (SV).

\begin{tabular}{|c|c|c|c|c|c|c|}
\hline \multirow[b]{2}{*}{ Scientific Criteria } & \multirow[b]{2}{*}{ Weight } & \multicolumn{2}{|c|}{ Craters } & \multicolumn{2}{|c|}{ Natural Sauna Points } & \multirow{2}{*}{$\begin{array}{c}\text { Thermal Spring } \\
\text { Panagia } \\
\text { Thermiani }\end{array}$} \\
\hline & & Stefanos & Polyvotis & Emporios & Piria & \\
\hline Representativeness & 30 & 3 & 3 & 2 & 2 & 2 \\
\hline Key locality & 20 & 2 & 2 & 2 & 1 & 2 \\
\hline Scientific knowledge & 5 & 4 & 4 & 2 & 2 & 2 \\
\hline Integrity & 15 & 4 & 4 & 4 & 4 & 4 \\
\hline Geological diversity & 5 & 4 & 4 & 2 & 2 & 2 \\
\hline Rarity & 15 & 3 & 3 & 2 & 2 & 2 \\
\hline Use limitations & 10 & 4 & 4 & 4 & 4 & 4 \\
\hline & & 315 & 315 & 250 & 230 & 250 \\
\hline Total score & & High & High & Moderate & Moderate & Moderate \\
\hline
\end{tabular}

$<200$ Low, 201-300 Moderate, >301 High [87].

Table 3. Quantitative evaluation of geosites for educational potential use (PEU).

\begin{tabular}{|c|c|c|c|c|c|c|}
\hline \multirow[b]{2}{*}{ Educational Criteria } & \multirow[b]{2}{*}{ Weight } & \multicolumn{2}{|c|}{ Craters } & \multicolumn{2}{|c|}{ Natural Sauna Points } & \multirow{2}{*}{$\begin{array}{c}\text { Thermal Spring } \\
\text { Panagia } \\
\text { Thermiani }\end{array}$} \\
\hline & & Stefanos & Polyvotis & Emporios & Piria & \\
\hline Vulnerability & 10 & 4 & 4 & 4 & 4 & 4 \\
\hline Accessibility & 10 & 4 & 4 & 4 & 1 & 4 \\
\hline Use limitations & 5 & 4 & 4 & 4 & 4 & 4 \\
\hline Safety & 10 & 3 & 3 & 3 & 3 & 3 \\
\hline Logistics & 5 & 4 & 4 & 4 & 4 & 4 \\
\hline Density of population & 5 & 3 & 3 & 3 & 3 & 3 \\
\hline Association with other values & 5 & 4 & 4 & 3 & 3 & 4 \\
\hline Scenery & 5 & 4 & 4 & 3 & 3 & 3 \\
\hline Uniqueness & 5 & 4 & 3 & 4 & 4 & 4 \\
\hline Observation conditions & 10 & 4 & 3 & 4 & 4 & 4 \\
\hline Didactic potential & 20 & 4 & 4 & 2 & 2 & 2 \\
\hline Geological diversity & 10 & 4 & 4 & 2 & 2 & 2 \\
\hline \multirow{2}{*}{ Total score } & & 385 & 370 & 315 & 285 & 320 \\
\hline & & High & High & High & Moderate & High \\
\hline
\end{tabular}

$<200$ Low, 201-300 Moderate, >301 High [87].

The application of the G-P method shows that no area has a low scientific value, and in fact, two of them have a fairly high score $(>301)$. Studying the educational potential of the areas, it is found that all sites present high scores, except for the geosite of Piria, which presents a moderate score (201-300). In terms of potential tourist use (PTU), it is observed that all geosites present high scores, which indicates the strong geotouristic dynamic of these places. Finally, checking the risk of degradation, it is found that all geosites have a low score, except for Emporios, which shows a moderate score (201-300). 
Table 4. Quantitative evaluation of geosites for tourism potential use (PTU).

\begin{tabular}{|c|c|c|c|c|c|c|}
\hline \multirow[b]{2}{*}{ Touristic Criteria } & \multirow[b]{2}{*}{ Weight } & \multicolumn{2}{|c|}{ Craters } & \multicolumn{2}{|c|}{ Natural Sauna Points } & \multirow{2}{*}{$\begin{array}{c}\text { Thermal Spring } \\
\text { Panagia } \\
\text { Thermiani }\end{array}$} \\
\hline & & Stefanos & Polyvotis & Emporios & Piria & \\
\hline Vulnerability & 10 & 4 & 4 & 4 & 4 & 4 \\
\hline Accessibility & 10 & 4 & 4 & 4 & 1 & 4 \\
\hline Use limitations & 5 & 4 & 4 & 4 & 4 & 4 \\
\hline Safety & 10 & 3 & 3 & 3 & 3 & 3 \\
\hline Logistics & 5 & 4 & 4 & 4 & 4 & 4 \\
\hline Density of population & 5 & 3 & 3 & 3 & 3 & 3 \\
\hline Association with other values & 5 & 4 & 4 & 3 & 3 & 4 \\
\hline Scenery & 15 & 4 & 4 & 3 & 3 & 3 \\
\hline Uniqueness & 10 & 4 & 3 & 4 & 4 & 4 \\
\hline Observation conditions & 5 & 4 & 3 & 4 & 4 & 4 \\
\hline Interpretative potential & 10 & 4 & 4 & 4 & 4 & 3 \\
\hline Economic level & 5 & 2 & 2 & 2 & 2 & 2 \\
\hline Proximity of recreational areas & 5 & 4 & 4 & 4 & 3 & 4 \\
\hline \multirow{2}{*}{ Total score } & & 375 & 360 & 355 & 325 & 350 \\
\hline & & High & High & High & High & High \\
\hline
\end{tabular}

$<200$ Low, 201-300 Moderate, >301 High [87].

Table 5. Degradation risk evaluation of geosites.

\begin{tabular}{ccccccc}
\hline & \multicolumn{2}{c}{ Craters } & \multicolumn{2}{c}{ Natural Sauna Points } & Thermal Spring \\
\hline Scientific Criteria & Weight & Stefanos & Polyvotis & Emporios & Piria & Panagia Thermiani \\
\hline $\begin{array}{c}\text { Deterioration of } \\
\text { geological features }\end{array}$ & 35 & 1 & 1 & 2 & 1 & 1 \\
\hline $\begin{array}{c}\text { Proximity to } \\
\text { areas /activities with } \\
\text { potential to cause } \\
\text { degradation }\end{array}$ & 20 & 1 & 1 & 4 & 1 & 4 \\
\hline $\begin{array}{c}\text { Legal protection } \\
\text { Accessibility }\end{array}$ & 20 & 2 & 2 & 2 & 4 & 2 \\
\hline Density of population & 15 & 4 & 3 & 4 & 1 & 4 \\
\hline Total score & 10 & 3 & 3 & 3 & 3 & 3 \\
\hline
\end{tabular}

$<200$ Low, 201-300 Moderate, >301 High [17,87].

Table 6. Final scores for G-P method.

\begin{tabular}{cccccc}
\hline \multirow{2}{*}{ Values } & \multicolumn{2}{c}{ Craters } & \multicolumn{2}{c}{ Natural Sauna Points } & Thermal Spring \\
\cline { 2 - 6 } & Stefanos & Polyvotis & Emporios & Piria & Panagia Thermiani \\
\hline Scientific & 315 & 315 & 250 & 230 & 250 \\
value & High & High & Moderate & Moderate & Moderate \\
Educational & 385 & 370 & 315 & 285 & 320 \\
value & High & High & High & Moderate & High \\
Tourism & 375 & 360 & 355 & 325 & 350 \\
value & High & High & High & High & High \\
\hline
\end{tabular}

\subsection{The M-GAM Method}

The application of the M-GAM quantitative evaluation method (Tables 7 and 8) reveals a corresponding picture of the results. In more detail, the geosite of Piria shows the lowest overall scores, whereas the craters of Stefanos and Polyvotis have the highest scores. These two geosites highlight important geoeducational elements, particularly magmatogenesis 
and the formation of geothermal fields. Remarkable scores also appear in the thermal water springs of Panagia Thermiani (GS5), Emporio (GS3), and Piria (GS4), where heat diffusion from the inside of the earth occurs due to the intense fault zones. Therefore, it can be said that the two methods show a fairly remarkable correlation. Moreover, this method may not take into account many parameters, but it includes, in addition to the opinion of experts, the opinion of visitors and the public.

Table 7. Calculation by M-GAM method of geosites $[36,86]$.

\begin{tabular}{|c|c|c|c|c|c|c|c|c|c|c|c|}
\hline \multicolumn{12}{|c|}{ M-GMAM Method } \\
\hline & \multicolumn{5}{|c|}{ Values Given by Experts } & & \multicolumn{5}{|c|}{ Total Value (with Im Factor) } \\
\hline & \multicolumn{2}{|c|}{ Craters } & \multicolumn{2}{|c|}{$\begin{array}{c}\text { Natural Sauna } \\
\text { Points }\end{array}$} & \multirow{2}{*}{$\begin{array}{l}\text { Thermal } \\
\text { Spring } \\
\text { Panagia } \\
\text { Ther- } \\
\text { miani }\end{array}$} & \multirow[b]{2}{*}{$\operatorname{Im}$} & \multicolumn{2}{|c|}{ Craters } & \multicolumn{2}{|c|}{$\begin{array}{c}\text { Natural Sauna } \\
\text { Points }\end{array}$} & \multirow{2}{*}{$\begin{array}{c}\text { Therma } \\
\text { Spring } \\
\text { Panagia } \\
\text { Ther- } \\
\text { miani }\end{array}$} \\
\hline & Stefanos & Polyvotis & Emporios & Piria & & & Stefanos & Polyvotis & Emporios & Piria & \\
\hline \multicolumn{12}{|l|}{ Main Values (MV) } \\
\hline \multicolumn{12}{|l|}{ Scientific/educational value (VSE) } \\
\hline 1. Rarity & 0.75 & 0.75 & 0.5 & 0.5 & 0.25 & 0.89 & 0.6675 & 0.6675 & 0.445 & 0.445 & 0.2225 \\
\hline 2. Representativeness & 0.75 & 0.75 & 0.5 & 0.5 & 0.25 & 0.79 & 0.5925 & 0.5925 & 0.395 & 0.395 & 0.1975 \\
\hline $\begin{array}{l}\text { 3. Knowledge of } \\
\text { scientific issues }\end{array}$ & 1.00 & 1.00 & 0.5 & 0.5 & 0.5 & 0.45 & 0.45 & 0.45 & 0.225 & 0.225 & 0.225 \\
\hline 4. Level of interpretation & 0.50 & 0.50 & 0.25 & 0.25 & 0.25 & 0.85 & 0.425 & 0.425 & 0.2125 & 0.2125 & 0.2125 \\
\hline \multicolumn{12}{|l|}{ Scenic/aesthetic (VSA) } \\
\hline 5. Viewpoints & 0.75 & 0.75 & 0.5 & 0.25 & 0.50 & 0.79 & 0.5925 & 0.5925 & 0.395 & 0.1975 & 0.395 \\
\hline 6. Surface & 1.00 & 1.00 & 0.5 & 0.50 & 0.50 & 0.54 & 0.54 & 0.54 & 0.27 & 0.27 & 0.27 \\
\hline $\begin{array}{l}\text { 7. Surrounding landscape and } \\
\text { nature }\end{array}$ & 1.00 & 1.00 & 0.75 & 0.75 & 0.50 & 0.95 & 0.95 & 0.95 & 0.7125 & 0.7125 & 0.475 \\
\hline $\begin{array}{l}\text { 8. Environmental fitting } \\
\text { of sites }\end{array}$ & 1.00 & 1.00 & 0.5 & 0.50 & 0.50 & 0.68 & 0.68 & 0.68 & 0.34 & 0.34 & 0.34 \\
\hline \multicolumn{12}{|l|}{ Protection (VPr) } \\
\hline 9. Current condition & 1.00 & 1.00 & 0.50 & 0.50 & 0.50 & 0.83 & 0.83 & 0.83 & 0.415 & 0.415 & 0.415 \\
\hline 10. Protection level & 0.75 & 0.75 & 0.25 & 0.25 & 0.25 & 0.76 & 0.57 & 0.57 & 0.19 & 0.19 & 0.19 \\
\hline 11. Vulnerability & 1.00 & 1.00 & 0.50 & 0.50 & 0.50 & 0.58 & 0.58 & 0.58 & 0.29 & 0.29 & 0.29 \\
\hline 12. Suitable number of visitors & 1.00 & 1.00 & 1.00 & 1.00 & 1.00 & 0.42 & 0.42 & 0.42 & 0.42 & 0.42 & 0.42 \\
\hline \multicolumn{12}{|l|}{ Additional values (AV) } \\
\hline \multicolumn{12}{|l|}{ Functional values (VFn) } \\
\hline 13. Accessibility & 1.00 & 1.00 & 1.00 & 0.25 & 1.00 & 0.75 & 0.75 & 0.75 & 0.75 & 0.1875 & 0.75 \\
\hline 14. Additional natural values & 0.75 & 0.75 & 0.75 & 0.50 & 0.50 & 0.71 & 0.5325 & 0.5325 & 0.5325 & 0.355 & 0.355 \\
\hline $\begin{array}{l}\text { 15. Additional anthropogenic } \\
\text { values }\end{array}$ & 0.75 & 0.75 & 0.50 & 0.25 & 0.50 & 0.70 & 0.525 & 0.525 & 0.35 & 0.175 & 0.35 \\
\hline 16. Vicinity of emissive centers & 0.00 & 0.00 & 0.25 & 0.00 & 0.00 & 0.48 & 0.00 & 0.00 & 0.12 & 0.00 & 0.00 \\
\hline $\begin{array}{l}\text { 17. Vicinity of important road } \\
\text { network }\end{array}$ & 0.25 & 0.25 & 0.25 & 0.00 & 0.25 & 0.62 & 0.155 & 0.155 & 0.155 & 0.00 & 0.155 \\
\hline 18. Additional functional values & 0.50 & 0.50 & 0.50 & 0.00 & 0.50 & 0.59 & 0.295 & 0.295 & 0.295 & 0.00 & 0.295 \\
\hline \multicolumn{12}{|l|}{ Touristic values (VTr) } \\
\hline 19. Promotion & 0.50 & 0.50 & 0.25 & 0.25 & 0.25 & 0.85 & 0.425 & 0.425 & 0.2125 & 0.2125 & 0.2125 \\
\hline 20. Organized visits & 1.00 & 1.00 & 1.00 & 0.00 & 0.75 & 0.56 & 0.56 & 0.56 & 0.56 & 0.00 & 0.42 \\
\hline 21. Vicinity of visitors' centers & 0.5 & 0.50 & 0.50 & 0.50 & 0.50 & 0.87 & 0.435 & 0.435 & 0.435 & 0.435 & 0.435 \\
\hline 22. Interpretative panels & 0.25 & 0.25 & 0.25 & 0.00 & 0.00 & 0.81 & 0.2025 & 0.2025 & 0.2025 & 0.00 & 0.00 \\
\hline 23. Number of visitors & 0.75 & 0.25 & 0.25 & 0.25 & 0.25 & 0.43 & 0.3225 & 0.1075 & 0.1075 & 0.1075 & 0.1075 \\
\hline 24. Tourism infrastructure & 0.75 & 0.75 & 0.50 & 0.00 & 0.25 & 0.73 & 0.5475 & 0.5475 & 0.365 & 0.00 & 0.1825 \\
\hline 25. Tour guide service & 0.25 & 0.25 & 0.00 & 0.00 & 0.00 & 0.87 & 0.2175 & 0.2175 & 0.00 & 0.00 & 0.00 \\
\hline 26. Hostelry service & 0.5 & 0.50 & 0.50 & 0.50 & 0.50 & 0.73 & 0.365 & 0.365 & 0.365 & 0.365 & 0.365 \\
\hline 27. Restaurant service & 1.00 & 1.00 & 1.00 & 0.50 & 0.75 & 0.78 & 0.78 & 0.78 & 0.78 & 0.39 & 0.585 \\
\hline
\end{tabular}

Table 8. Final results of the application of the M-GAM method.

\begin{tabular}{|c|c|c|c|c|c|}
\hline \multirow[t]{2}{*}{ Geosite } & \multirow{2}{*}{$\begin{array}{r}\text { Main Values } \\
\text { VSE + VSA + VPr }\end{array}$} & \multicolumn{4}{|c|}{ Additional Values } \\
\hline & & SUM & VFn + VTr & SUM & Field Area \\
\hline Stefanos crater & $2.135+2.7625+2.4$ & 7.2975 & $2.2575+3.855$ & 6.1125 & $\mathrm{Z} 22$ \\
\hline Polyvotis crater & $2.135+2.7625+2.4$ & 7.2975 & $2.2575+3.64$ & 5.8975 & $\mathrm{Z} 22$ \\
\hline Emporios (natural sauna) & $1.2775+1.7175+1.315$ & 4.31 & $2.2025+3.0275$ & 5.23 & $\mathrm{Z} 22$ \\
\hline Piria (natural sauna) & $1.2775+1.52+1.315$ & 4.1125 & $0.7175+1.51$ & 2.2275 & Z21 \\
\hline Panagia Thermiani (thermal spring) & $0.8575+1.48+1.315$ & 3.6525 & $1.905+2.3075$ & 4.2125 & Z11 \\
\hline
\end{tabular}


In more detail, the M-GAM method shows the highest scores for the two craters of Stefanos (GS1) and Polyvotis (GS2), respectively. Also, these two sites are geosites that highlight important geoeducational elements, especially the processes of magmatogenesis, creation, and deposition of geological formation, as well as hydrothermal vapors. In addition, with the second method, remarkable scores appear in three other sites: the thermal water springs of Panagia Thermiani (GS5), Emporio (GS3) and Piria (GS4), where the diffusion of heat from the inside of the earth occurs due to the intense fault zones. Therefore, from a geoeducational point of view, the public can be informed about the importance of fault zones and how more superficial geological formations can be affected. Therefore, students and visitors can understand in practice how the earth works internally and what effects it has. In addition, through the geosite of Panagia Thermiani, the meaning and significance of the hydrological cycle of water can be even better understood, since meteoric water and groundwater are united and influenced by endogenous forces, resulting in being warmer.

The diagram below (Figure 10) depicts the method's final results (Table 8). In terms of results, field $\mathrm{Z} 22$ contains three of the five areas investigated. In terms of geological peculiarities, these three areas share values and characteristics. Fields Z11 and Z21 each host one region with the lowest score when compared to the other three.

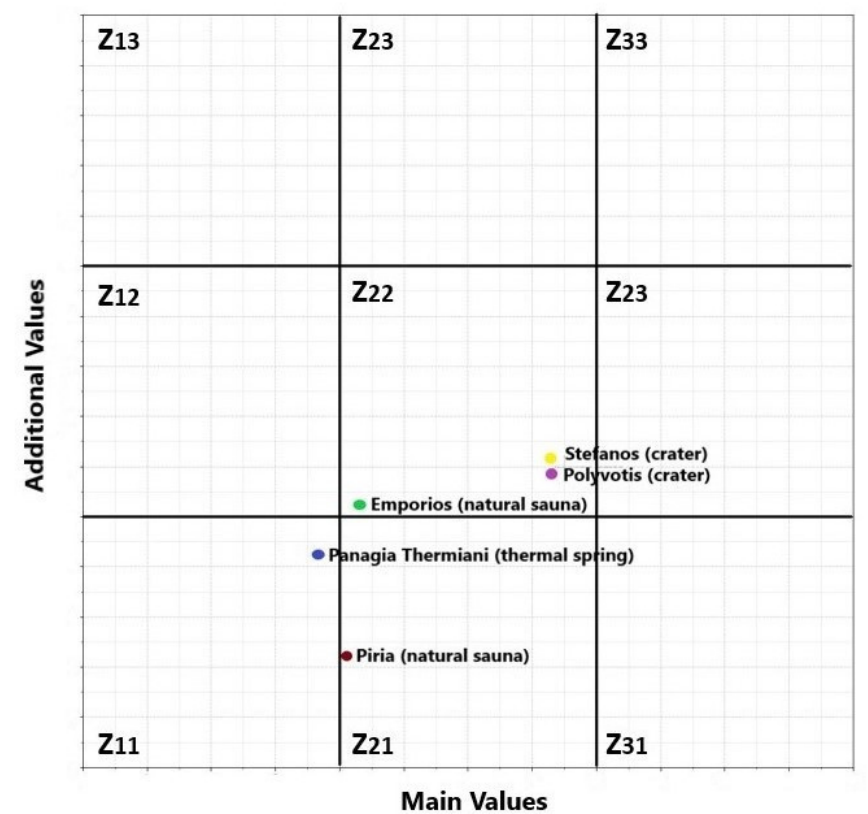

Stefanos crater $(7.9275-6.1125)$

Polyvotis crater (7.9275 - 5.8975)

Emporios natural sauna (4.31 - 5.23)

Piria natural sauna $(4.1125-2.2275)$

Panagia Thermiani $(3.6525-4.2125)$

thermal spring

Figure 10. The display of results from the M-GAM method.

\section{Discussion}

Comparative Analysis

"Telling the geological story of a protected area is the equivalent of telling people about a slice of Earth's history," writes Tormey [88]. In this sense, a site with significant geological and geomorphological features and processes must have educational value in order to help increase knowledge about dynamic phenomena that occur on the earth's surface on a continuous basis. The educational value of a specific geoheritage site will also aid in the conservation of natural resources, which is one of the key principles of Geotourism. The evaluation of educational value typically assesses the representativeness of the features or processes, exemplarity, and educational usage of the specific geoheritage site.

The goal of this study was to assess the geoeducational potential of five habitats on the volcanic island of Nisyros' aspiring geopark by employing two different methods, each with a different philosophy, comparing the results, and exploring the limitations 
that may be contained in each. The general-purpose Model (G-P method) was chosen because it examines a wide range of fields that are clearly graded and evaluated in terms of geoeducational potential. The M-GAM method, on the other hand, takes into account the opinions of visitors who, as non-experts, express a different point of view that is rarely calculated or evaluated in different geosite assessment methods.

The results were reduced to a percentage scale (\%) for a better and more objective comparison of the two methods of evaluating the educational potential of the study areas.

Table 9 displays the final results obtained from applying the methods, based on the grading scale for the geoeducational value of the respective geosites studied. In addition, the final score is recorded after the results have been converted and reduced to a common scale.

Table 9. Final results after the application of the two methods and after reduction to a common scale.

\begin{tabular}{|c|c|c|c|c|c|}
\hline \multirow[t]{2}{*}{ Geosites } & \multirow{2}{*}{$\begin{array}{l}\text { G-P } \\
\text { Method-Final } \\
\text { Score of } \\
\text { Education Use }\end{array}$} & \multicolumn{2}{|c|}{$\begin{array}{l}\text { M-GAM Method-Final Score of } \\
\text { Education Use }\end{array}$} & \multirow[t]{2}{*}{$\begin{array}{l}\text { Conversion to a } \\
\text { Percentage for } \\
\text { G-P Method }\end{array}$} & \multirow[t]{2}{*}{$\begin{array}{l}\text { Conversion to a } \\
\text { Percentage for } \\
\text { M-GAM Method }\end{array}$} \\
\hline & & Main Value & Additional Value & & \\
\hline GS1-Stefanos crater & 385 & 7.2975 & 6.1125 & 96.25 & 49.53 \\
\hline GS2-Megalos Polyvotis crater & 370 & 7.2975 & 5.8975 & 92.5 & 48.85 \\
\hline GS3-Thermal spring of Pyria & 315 & 4.31 & 5.23 & 78.75 & 35.26 \\
\hline GS4-Thermal spring of Emporios & 285 & 4.1125 & 2.2275 & 71.25 & 24.32 \\
\hline $\begin{array}{l}\text { GS5-Thermal spring of } \\
\text { Panagia Thermiani }\end{array}$ & 320 & 3.6525 & 4.2125 & 80.00 & 29.01 \\
\hline
\end{tabular}

According to the results shown in the table above, there is great difference in the values obtained by the application of the two evaluation methods. The first G-P method clearly highlights the high geological value of the studied geosites, which have a relatively high score and can be used for geotourism and geoeducation. Because it considers more fields and criteria, the G-P method more accurately testifies to and captures the dynamics of an area with strong geological features. This is accomplished by providing a more positive assessment and emphasizing both geographical and geoenvironmental value, both of which can be demonstrated to the general public through geoeducational activities.

The second method, on the other hand, yields a moderate score in areas with objectively high geological value. This is evidently becaause this method considers the opinions of visitors who do not have the necessary cognitive geological background, thus underestimating the importance and potential of certain geological features due to lack of formal training.

As a result, the comparison of the two methods reveals that the G-P method necessitates more parameters (12) to document the geoeducational value of the sites and approaches the geoeducational dimension of places of high geological interest in a broader and deeper manner. The second method, on the other hand, may not take into account as many parameters, but it does include, in addition to the opinion of experts, the opinion of visitors and the general public.

However, both assessment methods used in the current study clearly demonstrated that the geoeducational potential of the selected geosites can be developed. The G-P method clearly highlights the geoeducational potential of each geosite, because it includes didactic potential as a separate field in its analysis and gives it a special emphasis. It reveals that utilization is possible even at the highest educational level. As a result, the magnitude of the educational value and perspective became more understood, encouraging geoeducational activities aimed at primary, secondary, and higher education.

On the other hand, the low scores for the geoeducational potential of these geosites obtained using the M-GAM method are due to the inclusion of visitor feedback. The general public, who lacks sufficient geological knowledge, cannot comprehend the educational perspective and potential of a region with strong geological features. The lack of geoeduca- 
tional knowledge in culture becomes apparent, and the need for geoeducational activities to be implemented is identified. This will result in the dissemination and promotion of the geoheritage value of areas of high geological importance.

\section{Conclusions}

The island of Nisyros is undoubtedly a living geological laboratory, in which there are huge possibilities and prospects for the development of mainly geoeducational activities. In fact, the various geoeducational programs that can be implemented in the field will be able to contribute to the dissemination and promotion of geoeducation at various educational levels. In this way, issues such as geoheritage, geoethics, and geoconservation will become more understandable to each visitor and clear to the local community.

The two different methods implemented in this study could improve further evaluation of the geoeducational potential of five geosites located around the caldera of the volcanic island of Nisyros.

The first method, used by Brilha [17], is considered a general-purpose method (G-P method) designed to assess any type of geosite, considering a wide spectrum of criteria. The inclusion of 12 criteria for assessing the geoeducational value of studied geosites leads to more objective results. On the other hand, the M-GAM method incorporates the perspectives of the public, which in the present study clearly illustrates the lack of geoenvironmental awareness and knowledge.

The two methods provide different perspectives on the geoenvironmental value of a given geosite.

The first method addresses the geoeducational dimension of places of high geological interest in a broader and more in-depth way. The second method, while not taking into account as many parameters, does include the opinion of visitors and the general public.

For the most comprehensive evaluation of the geoeducational perspective on a geosite, the combination of the two aforementioned methods is considered necessary.

Author Contributions: Conceptualization, G.Z. and H.D.; methodology, G.Z. and H.D.; formal analysis, G.Z.; investigation, G.Z.; resources, G.Z.; data curation, G.Z.; writing-original draft preparation, G.Z.; writing-review and editing, H.D.; supervision, H.D. All authors have read and agreed to the published version of the manuscript.

Funding: This research received no external funding.

Informed Consent Statement: Not applicable.

Data Availability Statement: The data presented in this study are available on request from the corresponding author.

Acknowledgments: The authors gratefully thank the journal editor and the three reviewers for their thorough consideration of this paper.

Conflicts of Interest: The authors declare no conflict of interest.

\section{References}

1. Martini, G. (Ed.) Actes du premier symposium international sur la protection au patrimonie geologique. In Memoires de la Societe 656 geologique de France, Proceedings of the First Symposium on Earth Heritage Conservation, 11-16 June 1991; numero special 165; Société géologique de France: Digne, France, 1993; 276p.

2. Zouros, N. The European Geoparks Network. Episodes 2004, 27, 165-171.

3. Zouros, N.; Valiakos, I. Geoparks Management and Assessment. Bull. Geol. Soc. Greece 2017, 43, 965-977. [CrossRef]

4. Zwolinski, Z. Geodiversity. In Encyclopedia of Geomorphology; Goudie, A.S., Ed.; Routledge: Oxfordshire, UK, 2004; Volume 1, pp. $417-418$.

5. Sharples, C. Geoconservation in forest management-Principles and practice. Tasforests 1995, 7, 37-50.

6. Burek, C.V.; Potter, J. Local Geodiversity Action Plans-Sharing Good Practice Workshop, Peterborough, 3 December 2003; English Nature: Peterborough, UK, 2004.

7. Burek, C.V.; Potter, J. Local Geodiversity Action Plans-Setting to Context for Geological Conservation; English Nature: Peterborough, UK, 2006. 
8. Herrera-Franco, G.; Montalván-Burbano, N.; Carrión-Mero, P.; Apolo-Masache, B.; Jaya-Montalvo, M. Research trends in geotourism: A bibliometric analysis using the scopus database. Geosciences 2020, 10, 379. [CrossRef]

9. Ólafsdóttir, R.; Tverijonaite, E. Geotourism: A systematic literature review. Geosciences 2018, 8, 234. [CrossRef]

10. Panizza, M. Geomorphosites: Concepts, methods and examples of geomorphological survey. Chin. Sci. Bull. 2001, 46, 4-5. [CrossRef]

11. Trueba, J.J.G.; Cañadas, E.S. La valoración del patrimonio geomorfológico en espacios naturales protegidos. Su aplicación al parque nacional de los picos de Europa. Bull. Assoc. Span. Geogr. 2008, 47, 175-194, Published online 2008.

12. De Wever, P.; Baudin, F.; Pereira, D.; Cornee, A.; Egoroff, G.; Page, K. The Importance of Geosites and Heritage Stones in Cities-A Review. Geoheritage 2017, 9, 561-575. [CrossRef]

13. Reynard, E.; Fontana, G.; Kozlik, L.; Scapozza, C. A method for assessing the scientific and additional values of geomorphosites. Geogr. Helv. 2007, 62, 148-158. [CrossRef]

14. Ruban, D.A. Quantification of geodiversity and its loss. P. Geologist. Assoc. 2010, 121, 326-333. [CrossRef]

15. Ruban, D.A. Geotourism-A geographical review of the literature. Tour. Manag. Perspect. 2015, 15, 1-15. [CrossRef]

16. Skentos, A. Geotopes of Greece. Master's Thesis, University of Athens, Athens, Greece, 2012.

17. Brilha, J.B. Inventory and Quantitative Assessment of Geosites and Geodiversity Sites: A Review. Geoheritage 2016, 8, 119-134. [CrossRef]

18. Henriques, M.H.; Brilha, J. UNESCO Global Geoparks: A strategy towards global understanding and sustainability. Episodes 2017, 40, 349-355. [CrossRef]

19. Bruschi, V.M.; Coratza, P. Geoheritage and Environmental Impact Assessment (EIA). In Geoheritage: Assessment, Protection and Management; Reynard, E., Brilha, J., Eds.; Elsevier: Amsterdam, The Netherlands, 2018; pp. 251-264.

20. Zwoliński, Z.; Najwer, A.; Giardino, M. Methods for Assessing Geodiversity. In Geoheritage: Assessment, Protection, and Management; Reynard, E., Brilha, J., Eds.; Elsevier: Amsterdam, The Netherlands, 2018; pp. 27-52.

21. Drinia, H.; Tsipra, T.; Panagiaris, G.; Patsoules, M.; Papantoniou, C.; Magganas, A. Geological heritage of Syros Island, Cyclades complex, Greece: An assessment and geotourism perspectives. Geosciences 2021, 11, 138. [CrossRef]

22. Fassoulas, C.; Mouriki, D.; Dimitriou-Nikolakis, P.; Iliopoulos, G. Quantitative Assessment of Geotopes as an Effective Tool for Geoheritage Management. Geoheritage 2012, 4, 177-193. [CrossRef]

23. Cendrero, A. El patrimonio geológico. Ideas para su protección, conservación y utilización. In El patrimonio geológico. Bases para su valoración, protección, conservación y utilización; Serie Monografías del Ministerio de Obras Públicas, Transportes y Medio Ambiente; Ministerio de Obras Públicas, Transportes y Medio Ambiente: Madrid, Spain, 1996; pp. 17-27.

24. Cendrero, A. Propuestas sobre criterios para la clasificación y catalogación del patrimonio geológico. In El patrimonio geológico. Bases para su valoración, protección, conservación y utilización; Serie Monografías del Ministerio de Obras Públicas, Transportes yMedio Ambiente; Ministerio de Obras Públicas, Transportes y Medio Ambiente: Madrid, Spain, 1996; pp. $29-38$.

25. Coratza, P.; Giusti, C. Methodological proposal for the assessment of the scientific quality of geomorphosites. Il Quat. 2005, 18, 307-313.

26. Pralong, J.P.; Reynard, E. A proposal for the classification of geomorphological sites depending on their tourist value. Quaternario 2005, 18, 315-321.

27. Pereira, P.; Pereira, D.; Alves, M.I.C. Geomorphosite assessment in Montesinho Natural Park (Portugal). Geogr. Helv. 2007, 62, 159-168. [CrossRef]

28. Bruschi, V.M.; Cendrero, A. Direct and parametric methods for the assessment of geosites and geomorphosites. In Geomorphosites; Reynard, E., Coratza, P., Regolini-Bissig, G., Eds.; Verlag Dr. Friedrich Pfeil: München, Germany, 2009; pp. 73-88.

29. Reynard, E. The assessment of geomorphosites. In Geomorphosites; Reynard, E., Coratza, P., Regolini Bissig, G., Eds.; Verlag Dr. Friedrich Pfeil: Munchen, Germany, 2009; pp. 63-71.

30. Pereira, P.; Pereira, D. Methodological guidelines for geomorphosite assessment. Géomorphologie: Relief, processus. Environnement 2010, 16, 215-222.

31. Bruschi, V.M.; Cendrero, A.; Albertos, J.A.C. A statistical approach to the validation and optimisation of geoheritage assessment procedures. Geoheritage 2011, 3, 131-149. [CrossRef]

32. Pereira, P.; Pereira, D.I. Assessment of geosites tourism value in geoparks: The example of Arouca Geopark (Portugal). In Proceedings of the 11th European Geoparks Conference, Arouca, Portugal, 19-21 September 2012; pp. 231-232.

33. Bollati, I.; Smiraglia, C.; Pelfini, M. Assessment and selection of geomorphosites and trails in the Miage Glacier area (Western Italian Alps). Environ. Manag. 2013, 51, 951-967. [CrossRef] [PubMed]

34. Gray, M. Geodiversity: Valuing and Conserving Abiotic Nature; Wiley: Chichester, UK, 2004; p. 448.

35. Brilha, J.; Gray, M.; Pereira, D.I.; Pereira, P. Geodiversity: An integrative review as a contribution to the sustainable management of the whole of nature. Environ. Sci. Policy 2018, 86, 19-28. [CrossRef]

36. Tomić, N.; Božić, S. A modified geosite assessment model (MGAM) and its application on the Lazar Canyon area (Serbia). Int. J. Environ. Res. 2014, 8, 1041-1052.

37. Antić, A.; Tomić, N.; Marković, S.B. Karst geoheritage and geotourism potential in the Pek River lower basin (eastern Serbia). Geogr. Pannoni. 2019, 23, 32-46. [CrossRef]

38. Gray, M. Geodiversity: Valuing and Conserving Abiotic Nature, 2nd ed.; Wiley-Blackwell: Hoboken, NJ, USA, 2013 ; pp. 3-14. 
39. Megía, M.V.; Alarcón, J.C.B.; Romero, J.S.G.; Muñoz, A.B.P. El inventario andaluz de georrecursos culturales: Criterios de valoración. Rev. Soc. Española Def. Patrim. Geológico Min. 2004, 3, 9-22.

40. Kozlowski, S. Geodiversity. The concept and scope of geodiversity. Prz. Geol. 2004, 52, 833-837.

41. Vujičić, M.D.; Vasiljević, Đ.A.; Marković, S.B.; Hose, T.A.; Lukić, T.; Hadžić, O.; Janićević, S. Preliminary geosite assessment model (GAM) and its application on Fruška Gora Mountain, potential geotourism destination of Serbia. Acta Geogr. Slov. 2011, 51, 361-377. [CrossRef]

42. Tomić, N. The potential of Lazar Canyon (Serbia) as a geotourism destination: Inventory and evaluation. Geogr. Pannonica 2011, 15, 103-112. [CrossRef]

43. Dietrich, V.J.; Lagios, E. (Eds.) Nisyros Volcano, Active Volcanoes of the World; Springer: Berlin, Germany, 2018 ; pp. 13-55. ISBN 978-3-319-55458-7.

44. Papanikolaou, D.; Lekkas, E.; Sakellariou, D. Geological structure and evolution of the Nisyros volcano. Bull. Geol. Soc. Greece 1991, 25, 405-419.

45. Tibaldi, A.; Pasquarè, F.A.; Papanikolaou, D.; Nomikou, P. Tectonics of Nisyros Island, Greece, by field and offshore data, and analogue modeling. J. Struct. Geol. 2008, 30, 1489-1506. [CrossRef]

46. Francalanci, L.; Vougioukalakis, G.E.; Perini, G.; Manetti, P. A West-East Traverse along the magmatism of the south Aegean volcanic arc in the light of volcanological, chemical and isotope data. Dev. Volcanol. 2005, 7, 65-111.

47. Khaleghi, M.; Ranjbar, H.; Abedini, A.; Calagari, A.A. Synergetic use of the Sentinel-2, ASTER, and Landsat-8 data for hydrothermal alteration and iron oxide minerals mapping in a mine scale. Acta Geodyn. Geromater. 2020, 17, 311-329. [CrossRef]

48. Rajan Girija, R.; Mayappan, S. Mapping of mineral resources and lithological units: A review of remote sensing techniques. Int. J. Image Data Fusion. 2019, 10, 79-106. [CrossRef]

49. Di Paola, G.M. Volcanology and petrology of Nisyros Island (Dodecanese, Greece). Bull. Volcanol. 1974, 38, 944-987. [CrossRef]

50. Hunziker, J.C.; Marini, L. (Eds.) The geology, Geochemistry and Evolution of Nisyros Volcano (Greece): Implications for the Volcanic Hazards; Section des sciences de la Terre, Université de Lausanne: Lausanne, Switzerland, 2005; Volume 44.

51. Martelli, A. II gruppo eruttivo di Nisiro nel Mare Egeo, 1917, Memorie della Societa Italiano della Scienze detta dei XL Serie 3a T. XX; Accademia dei Lincei: Rome, Italy, 1917.

52. Marini, L.; Fiebig, J. Fluid geochemistry of the magmatic-hydrothermal system of Nisyros (Greece). In The Geology, Geochemistry and Evolution of Nisyros Volcano; Mémoire de Géologie: Lausanne, Switzerland, 2005.

53. Ambrosio, M.; Doveri, M.; Fagioli, M.T.; Marini, L.; Principe, C.; Raco, B. Water-rock interaction in the magmatic-hydrothermal system of Nisyros Island (Greece). J. Volcanol. Geother. Res. 2010, 192, 57-68. [CrossRef]

54. Gorceix, M.H. Sur l'état du volcan de Nisyros au mois de mars 1873. C. R. Seances Acad. Sci. Paris 1873, 77, 597-601.

55. Gorceix, M.H. Sur l'éruption boueuse de Nisyros. C. R. Seances Acad. Sci. 1873, 77, 1474-1477.

56. Gorceix, M.H. Etude des fumerolles de Nisyros et de quelques-uns des produits des éruptions dont cette ile a été le siège en 1872 et 1873. Ann. Chim. Phys. Paris 1874, 333-354.

57. Marini, L.; Principe, C.; Chiodini, G.; Cioni, R.; Fytikas, M.; Marinelli, G. Hydrothermal eruptions of Nisyros (Dodecanese, Greece). Past events and present hazard . J. Volcanol. Geother. Res. 1993, 56, 71-94. [CrossRef]

58. Vassilopoulou, S.; Hurni, L. The use of digital elevation models in emergency and socio-economic planning: A case study at Kos-Yali-Nisyros-Tilos islands, Greece. In Proceedings of the 20th International Cartographic Conference, Beijing, China, 6-10 August 2001; Chinese Society of Geodesy, Photogrammetry and Cartography: Beijing, China; pp. 3424-3431.

59. Desio, A. Le isole italiane dell'Egeo. Mem. Carta Geol. D'Ital. 1931, 24, 534.

60. Davis, E.N. Zur geolofie und Petrologie der Inseln Nisyros und Jail (Dodekanes). Prakt. Acad. Athens 1967, 42, 235-252.

61. Piper, D.J.W.; Pe-Piper, G.; Anastasakis, G.; Reith, W. The volcanic history of Pyrgousa-Volcanism before the eruption of the Kos Plateau Tuff. Bull. Volcanol. 2019, 81, 32. [CrossRef]

62. Papanikolaou, D.; Nomikou, P. Tectonic structure and volcanic centres at the eastern edge of the Aegean volcanic arc around Nisyros Island. Bull. Geol. Soc. Greece 2001, 34, 289-296. [CrossRef]

63. Lagios, E.; Sakkas, V.; Parcharidis, I.; Dietrich, V. Ground Deformation of Nisyros Volcano (Greece) for the period 1995-2002: Results from DInSAR and DGPS observations. Bull. Volcanol. 2005, 68, 201-214. [CrossRef]

64. Papadopoulos, G.A.; Sachpazi, M.; Panopoulou, G.; Stavrakakis, G. The volcanoseismic crisis of 1996-1997 in Nisyros, SE Aegean Sea, Greece. Terra Nova 1998, 10, 151-154. [CrossRef]

65. GEOWARN-IST 12310. Geological Map of Greece, 1:10,000. Geo-SpatialWarning Sys-tems Nisyros Volcano (Greece): An Emergency Case Study. Information Society Tech-nologies Programme. Available online: www.geowarn.ethz.ch (accessed on 13 January 2022)

66. Sykioti, O.; Kontoes, C.; Elias, P.; Briole, P.; Sachpazi, M.; Paradissis, D.; Kotsis, I. Ground deformation at Nisyros volcano (Greece) detected by ERS-2 SAR differential interferometry. Int. J. Remote Sens. 2003, 24, 183-188. [CrossRef]

67. Venturi, S.; Tassi, F.; Vaselli, O.; Vougioukalakis, G.E.; Rashed, H.; Kanellopoulos, C.; Caponi, C.; Capecchiacci, F.; Cabassi, J.; Ricci, A.; et al. Active hydrothermal fluids circulation triggering small-scale collapse events: The case of the 2001-2002 fissure in the Lakki Plain (Nisyros Island, Aegean Sea, Greece). Nat. Hazards 2018, 93, 601-626. [CrossRef]

68. Chiodini, G.; Cioni, R.; Marini, L. Reactions governing the chemistry of crater fumaroles from Vulcano Island, Italy, and implications for volcanic surveillance. Appl. Geochem. 1993, 8, 357-371. [CrossRef] 
69. Kavouridis, T.; Kuris, D.; Leonis, C.; Liberopoulou, V.; Leontiadis, J.; Panichi, C.; La Ruffa, G.; Caprai, A. Isotope and chemical studies for a geothermal assessment of the island of Nisyros (Greece). Geothermics 1999, 28, 219-239. [CrossRef]

70. Chiodini, W.; Brombach, T.; Caliro, S.; Cardellini, C.; Marini, L.; Dietrich, V. Geochemical indicators of possible ongoing volcanic unrest at Nisyros Island (Greece). Geophys. Res. Lett. 2002, 29, 1759. [CrossRef]

71. Brombach, T.; Caliro, S.; Chiodini, G.; Fiebig, J.; Hunziker, J.C.; Raco, B. Geochemical evidence for mixing of magmatic fluids with seawater, Nisyros hydrothermal system, Greece. Bull. Volcanol. 2003, 65, 505-516. [CrossRef]

72. Dotsika, E.; Poutoukis, D.; Michelot, J.; Raco, B. Natural tracers for identifying the origin of the thermal fluids emerging along the Aegean Volcanic arc (Greece): Evidence of Arc-Type Magmatic Water (ATMW) participation. J. Volcanol. Geotherm. Res. 2009, 179, 19-32. [CrossRef]

73. Carcavilla Urquí, L.; López Martínez, J.; Durán Valsero, J.J. Patrimonio Geológico y Geodiversidad: Investigación, Conservación, Gestión y Relación Cuadernos; Instituto Geológico y Minero de España (IGME): Madrid, Spain, 2007; ISBN 9788478407101.

74. Fuertes-Gutiérrez, I.; Fernández-Martínez, E. Mapping geosites for geoheritage management: A methodological proposal for the Regional Park of Picos de Europa (León, Spain). Environ. Manag. 2012, 50, 789-806. [CrossRef] [PubMed]

75. Vuković, S.; Antić, A. Speleological approach for geotourism development in Zlatibor county (west Serbia). Turizam 2019, 23, 53-68. [CrossRef]

76. Tomić, N.; Antić, A.; Marković, S.B.; Đorđević, T.; Zorn, M.; Breg Valjavec, M. Exploring the potential for speleotourism development in eastern Serbia. Geoheritage 2019, 11, 359-369. [CrossRef]

77. Tičar, J.; Tomić, N.; Breg Valjavec, M.; Zorn, M.; Marković, S.B.; Gavrilov, M.B. Speleotourism in Slovenia: Balancing between mass tourism and geoheritage protection. Open Geosci. 2018, 10, 344-357. [CrossRef]

78. Antić, A.; Tomić, N. Assessing the speleotourism potential together with archaeological and palaeontological heritage in Risovača Cave (Central Serbia). Acta Geoturistica 2019, 10, 1-11.

79. Miljković, Đ.; Božić, S.; Miljković, L.; Marković, S.B.; Lukić, T.; Jovanović, M.; Bjelajac, D.; Vasiljević, Đ.A.; Vujičić, M.D.; Ristanović, B. Geosite assessment using three different methods; a comparative study of the Krupaja and the Žagubica Springs - Hydrological Heritage of Serbia. Open Geosci. 2018, 10, 192-208. [CrossRef]

80. Pál, M.; Albert, G. Comparison of geotourism assessment models: And experiment in Bakony-Balaton UNSECO Global Geopark, Hungary. Acta Geoturistica 2018, 9, 1-13. [CrossRef]

81. Jonić, V. Comparative analysis Devil's town and Bryce canyon geosites by applying the modified geosite assessment model (M-GAM). Researches Review the Department Geography. Tour. Hotel Manag. 2018, 47, 113-125. [CrossRef]

82. Antić, A.; Tomić, N. Geoheritage and geotourism potential of the Homolje area (eastern Serbia). Acta Geoturistica 2017, 8, 67-78. [CrossRef]

83. Vukoičić, D.; Milosavljević, S.; Valjarević, A.; Nikolić, M.; Srećković-Batoćanin, D. The evaluation of geosites in the territory of National park 'Kopaonik' (Serbia). Open Geosci. 2018, 10, 618-633. [CrossRef]

84. Tomić, N.; Marković, S.B.; Korać, M.; Mrđić, N.; Hose, T.A.; Vasiljević, D.A.; Jovičić, M.; Gavrilov, M.B. Exposing mammoths: From loess research discovery to public palaeontological park. Quat. Int. 2015, 372, 142-150. [CrossRef]

85. Tomić, N.; Marković, S.B.; Antić, A.; Tešić, D. Exploring the potential for geotourism development in the Danube Region of Serbia. Int. J. Geoheritage Park. 2020, 8, 123-139. [CrossRef]

86. Božić, S.; Tomić, N. Canyons and gorges as potential geotourism destinations in Serbia: Comparative analysis from two perspectives-General geotourists' and pure geotourists'. Open Geosci. 2015, 7, 531-546. [CrossRef]

87. Lima, F.F. Proposta metodológica para inventariação do patrimônio geológico brasileiro. Dissertação (Mestrado em Patrimônio Geológico e Conservação); Universidade do Minho: Braga, Portugal, 2008.

88. Tormey, D. New approaches to communication and education through geoheritage. Int. J. Geoheritage Park. 2019, 7, 192-198. [CrossRef] 